\title{
Trends, Growth and Changing Patterns of Public Expenditure on Education in India
}

\section{Tasleem Araf C*}

Department of Economics, Central University of Kashmir, India

\begin{abstract}
The paper examines the level, trends, growth and intra-sectoral allocation of Public expenditure on education. Finding indicates that quantum of expenditure on education has increased significantly since 2001, But still the actual amount of money spend on education sector is less than the required amount. The paper explores the trends of public expenditure on education, like, trends on planned and Non planned expenditure, Revenue and Capital expenditure. The paper also throws light on trends in intra sect oral allocation public expenditure i.e. expenditure on primary, secondary, higher education and technical education. Trends also found in expenditure incurred by State government and central government. Analysis shows that percentage share of State government has decline and the share of central government has increased. Some Trends has also been found in planned and Non planned expenditure on education. Share of former has increased and share of later has decline. No major trends have been found on Revenue and capital account expenditure. Capital account expenditure is meagre amount of the total expenditure.
\end{abstract}

Keywords: Public expenditure; Education; Budget; Revenue account; Capital account

\section{Introduction}

Education is most important components of social sector. Education is public good and it is included in the concurrent list of Indian constitution, both Central and state government has the responsibility to maintain quantity, quality, access and equity in education. Financial resource spend by the government on any sector indicates the importance attached to that sector. Expenditure on education is considered as investment on human capital; it raises the level of skill and therefore productivity of worker and thus contributes to economic growth and development of the country. Some studies show that countries spend large money on education grows as faster rate compared with countries spend less on education. Availability of financial resources is important determinants for quantitive expansion and qualitative improvement of educational sector. Our education system has severely starved of funds. It requires huge flow of funds for its quantative expansion, qualitatively improvement and for universal access.

\section{Sources of financing education}

There are several sources of financing education - Public sector which includes expenditure incurred by the central government, state governments and union territories government, and local bodies. In addition to government, Non-governmental agencies, corporate investment and individual household spending also contribute significantly. But the roles of the government still remain pervasive and important. The focus in this paper has been essentially on public expenditure on education by the central and the state government. The state has lion share with more than one third in the total expenditure.

\section{Financial requirement of education sector}

The government has constitutes commissions and appointed various committees to estimate the financial requirement of educational sector. The education commission 1964-66 popularly known as kathori commission made a detailed analysis of financial requirement of educational sector, and recommended that we should increase the proportion of GDP spend on education to 6 percent of GDP by 1985-86. Among other recommendation this recommendation was accepted by the government and it was decided to raise the spending on education to 6 percent of GDP by 1986 . National education policy 1968 also recommended that investment on education should increase gradually to six percent of national income as soon as possible. It was resolved in the National educational policy of 1986, to increase the investment on education so as to reach the level of 6 percent of national income. But the goal remained unfulfilled. Saikia committee 1996 stressed on the need for an expenditure of six percent of GDP on education with 50 percent of it earmarked for the primary sector. In The common Minimum programme of the UPA government it was decided that public spending on education will be raised to 6 percent of the GDP and that will be in the phased manner. With this background the present study tries to analyse the level and composition of public expenditure on education sector.

\section{Objective of the Study}

The objectives of the paper is to provide comprehensive assessment of the expenditure incurred both by Central and State Government on education, The primary focus of the study is on the following objectives:-

- To know the amount of money spent by Centre, State and union territories government on education

- To find the trends and growth of public expenditure on education

- To know the changing Patterns of government expenditure at different components of public expenditure on education

*Corresponding author: Tasleem Araf C, Department of Economics, Central University of Kashmir, India, Tel: 9086021737; E-mail: arafmughaleco@gmail.com

Received October 27, 2016; Accepted November 28, 2016; Published December 05, 2016

Citation: Tasleem Araf C (2016) Trends, Growth and Changing Patterns of Public Expenditure on Education in India. J Glob Econ 4: 226. doi: 10.4172/23754389.1000226

Copyright: (C) 2016 Tasleem Araf C. This is an open-access article distributed under the terms of the Creative Commons Attribution License, which permits unrestricted use, distribution, and reproduction in any medium, provided the original author and source are credited. 
- To know the level and trends of intra- sectoral allocation of Public expenditure

\section{Methodology}

The Study covers the period 2000-01 to 2013-14 and primarily base on secondary data collected from budgetary Analysis of Govt expenditure (Ministry of Human Resource Development Government of India). Data is also obtained from University Grant Commission (UGC) annual reports. The research tools and concepts used for the study include percentage, growth rate etc.

\section{Review of Literature}

There have been several studies on expenditure on education in recent times which provide valuable inputs to this paper. Important among them are:-

Anuradha De et al. [1] in their working paper on the title "Public Expenditure on Education in India, Recent Trends and Outcomes" found that public expenditure on education in current prices has been growing at the compound annual growth rate (CAGR) of 13.4 per cent p.a. for the period 1990-91 to 2003-04 the rate of growth has slowed down in the present decade. Moreover their study indicates that expenditure in constant prices shows a much lower CAGR of only 6.5 percent for the same period. Though the expenditure has almost doubled between 1990-01 to 2000-01, it had stagnated and even decline since then. As a proportion of GDP the share of public expenditure on education has been less than 4 per cent. There have been major changes in the composition and modalities of expenditure on education. The analysis finds that the centre has been playing an increasingly important role in state education finance.

Jandhyala [2] in his paper on the title "On Allocating 6 Percent of GDP to Education" found that under investment in education is regarded as one of the main reasons for failure in realising our educational goals and targets. He concludes that allocation to education can be increased by reallocation resources from other sources or by raising more resources from the common pool of government funds or by both.

\section{Public Expenditure on Education in India}

Centre, State and Union-Territories government are the main sources of financing education sectors; with State government has lion share. Share of the State government has decline but still State government contributes more than one third of total expenditure on education. The paper primarily used data from Analysis of Budgeted Expenditure on Education (Ministry of Human Resource Development). The data presented in these reports take into account the expenditure incurred on education by all departments in addition to that by the education department, and is the standard source used for analyzing public expenditure on education. However much of the data used in this paper are expenditures by education Department of the relevant governments on revenue account. We next take a look at the budget expenditure on education, its share in GDP and the Plan-Non plan distribution of public expenditure on education. During the last one and half decade some major trends have been found in financing education. The share of state government in total expenditure has declines from $88 \%$ in $2000-01$ to $74 \%$ in $2013-14$. Percentage Share of central government has increased significantly during the same period from 12 percent in 2000-01 to 26 percent in 2013-14. The notable feature of the is real expenditure on education which is obtained by dividing nominal expenditure with the GDP deflator. Real expenditure shows the real amount of money spend on this sector by eliminating the effect of inflation. If we look at the percentage of GDP spend on education for both Centre and States [3]. we found an increasing trend over the years the percentage of GDP spend on education gone up from $0.51 \%$ in $2000-01$ to $1.19 \%$ in $2013-14$, The percentage of GDP spend by state government shows a declining trends state's share has declined from $3.63 \%$ in the year $2000-01$ to $2.53 \%$ in $2007-08$ thereafter it has increases and reached at 3.26 percent in 2013-14 Table 1.

It is seen from Table. 1 that Nominal expenditure on education has increases five times since 2001. Total expenditure on education incurred by both centre and state been growing at the annual average growth rate-percent. Moreover Real expenditure i.e expenditure on constant prices shows a much lower CAGR of only 6.5 percent for the same period. It has also been analysed from the table that the share of state government in total expenditure has decline from $88 \%$ in 2001 to 74 percent in 2013-14. The share of central government has increased significantly from 12 percent in 2001 to 26 percent in 2013-14. Public expenditure on education as percentage of total expenditure of the government has reached the highest level 14.60 percent; thereafter it stared declining at become 13.63 in 2008-09.

\begin{tabular}{|c|c|c|c|c|c|c|c|c|}
\hline \multirow[t]{2}{*}{ Years } & \multicolumn{2}{|c|}{ Expenditure on Education } & \multirow[t]{2}{*}{ Total } & \multirow[t]{2}{*}{ Growth rate } & \multirow{2}{*}{$\begin{array}{l}\% \text { Share of } \\
\text { centre }\end{array}$} & \multirow[t]{2}{*}{$\%$ Share of state } & \multirow{2}{*}{$\begin{array}{c}\text { State as } \% \text { of } \\
\text { GDP }\end{array}$} & \multirow{2}{*}{$\begin{array}{c}\text { State+Centre as } \\
\% \text { of GDP }\end{array}$} \\
\hline & Centre & State & & & & & & \\
\hline $2000-01$ & 10195 & 72290 & 82486 & - & 12 & 88 & 3.63 & 4.14 \\
\hline $2001-02$ & 14119 & 65746 & 79865 & -3.17 & 18 & 82 & 3.03 & 3.68 \\
\hline $2002-03$ & 16156 & 69350 & 85506 & 7.06 & 19 & 81 & 2.97 & 3.66 \\
\hline 2003-04 & 17101 & 71798 & 89079 & 4.01 & 19 & 81 & 2.74 & 3.40 \\
\hline 2004-05 & 18026 & 78668 & 96694 & 8.54 & 19 & 81 & 2.65 & 3.26 \\
\hline $2005-06$ & 23209 & 90019 & 113228 & 17.09 & 21 & 79 & 2.66 & 3.34 \\
\hline $2006-07$ & 34236 & 103148 & 137384 & 21.23 & 25 & 75 & 2.61 & 3.48 \\
\hline $2007-08$ & 39919 & 115878 & 155797 & 13.40 & 26 & 74 & 2.53 & 3.40 \\
\hline 2008-09 & 48728 & 143667 & 192395 & 23.49 & 25 & 75 & 2.66 & 3.56 \\
\hline $2009-10$ & 54146 & 188636 & 246782 & 28.26 & 24 & 76 & 2.90 & 3.95 \\
\hline $2010-11$ & 80661 & 212817 & 293478 & 18.92 & 28 & 72 & 2.94 & 4.05 \\
\hline 2011-12 & 86074 & 251008 & 337082 & 14.85 & 26 & 74 & 2.95 & 3.98 \\
\hline $2012-13$ & 103312 & 311426 & 414738 & 23.03 & 25 & 75 & 3.25 & 4.35 \\
\hline $2013-14$ & 124118 & 347893 & 472011 & 13.80 & 26 & 74 & 3.26 & 4.44 \\
\hline
\end{tabular}

Source: Ministry of Human Resources Govt of India. (Budgetary Analysis) various issues [3]

Table 1: Public Expenditure on education since 2000-01. 
Citation: Tasleem Araf C (2016) Trends, Growth and Changing Patterns of Public Expenditure on Education in India. J Glob Econ 4: 226. doi: 10.4172/2375-4389.1000226

Page 3 of 4

\begin{tabular}{|c|c|c|c|c|c|c|}
\hline \multirow[t]{2}{*}{ Years } & \multicolumn{2}{|c|}{ Centre } & \multicolumn{2}{|c|}{ State } & \multicolumn{2}{|c|}{ Total centre and state } \\
\hline & Plan & Non-plan & Plan & Non-Plan & Plan & Non-Plan \\
\hline 2004-05 & 71.43 & 28.57 & 12.45 & 87.55 & 23.88 & 76.55 \\
\hline $2005-06$ & 76.97 & 23.03 & 15.32 & 84.68 & 27.92 & 71.08 \\
\hline $2006-07$ & 81.04 & 18.94 & 16.48 & 83.52 & 32.52 & 67.48 \\
\hline $2007-08$ & 82.42 & 17.58 & 16.71 & 83.28 & 33.55 & 66.45 \\
\hline $2008-09$ & 79.67 & 20.33 & 16.47 & 83.53 & 32.51 & 67.49 \\
\hline $2009-10$ & 74.19 & 25.81 & 16.56 & 83.48 & 31.86 & 68.14 \\
\hline $2010-11$ & 80.22 & 19.78 & 20.54 & 79.46 & 35.92 & 64.08 \\
\hline $2011-12$ & 73.40 & 26.60 & 24.28 & 75.72 & 36.70 & 63.30 \\
\hline $2012-13$ & 73.33 & 26.67 & 23.52 & 76.48 & 37.00 & 63.00 \\
\hline $2013-14$ & 74.41 & 25.59 & 25.23 & 74.77 & 38.34 & 61.66 \\
\hline
\end{tabular}

Source: Calculated from Analysis of Budgeted Expenditure on Education, Ministry of HRD, Govt. of India various issues [3].

Table 2: Share of plan and Non-plan expenditure on education Revenue Account.

\begin{tabular}{|c|c|c|c|c|c|}
\hline Years & $\begin{array}{l}\text { Elementary } \\
\text { Sector }\end{array}$ & $\begin{array}{l}\text { Secondary } \\
\text { sector }\end{array}$ & $\begin{array}{l}\text { University and } \\
\text { Higher education }\end{array}$ & Technical education & $\begin{array}{l}\text { Others sector including } \\
\text { adult, etc. }\end{array}$ \\
\hline $2001-02$ & 50.91 & 33.80 & 11.34 & 2.32 & 1.64 \\
\hline $2002-03$ & 49.12 & 34.91 & 11.95 & 2.42 & 1.59 \\
\hline 2003-04 & 49.57 & 34.95 & 11.61 & 2.28 & 1.59 \\
\hline 2004-05 & 51.45 & 30.13 & 11.67 & 3.82 & 2.93 \\
\hline $2005-06$ & 46.56 & 25.80 & 19.31 & 7.96 & 0.89 \\
\hline $2006-07$ & 45.17 & 23.27 & 19.30 & 11.98 & 0.28 \\
\hline $2007-08$ & 44.62 & 22.98 & 24.47 & 7.67 & 0.26 \\
\hline 2008-09 & 42.47 & 24.24 & 24.30 & 8.79 & 0.20 \\
\hline $2009-10$ & 39.63 & 25.87 & 23.59 & 8.91 & 2.0 \\
\hline $2010-11$ & 42.09 & 24.31 & 21.34 & 11.95 & 0.31 \\
\hline $2011-12$ & 44.66 & 25.62 & 16.14 & 13.28 & 0.30 \\
\hline $2012-13$ & 45.21 & 25.19 & 14.70 & 14.62 & 0.28 \\
\hline 2013-14 & 44.59 & 24.86 & 15.29 & 14.95 & 0.31 \\
\hline
\end{tabular}

Sources: Calculated from Analysis of Budgeted Expenditure on Education, Ministry of HRD, Govt. of India various issues [3].

Table 3: Intra Sectoral allocation of Public Expenditure on education in India since 2001-02.

\section{Components of Public Expenditure}

Components of Public expenditure on any sector are planned expenditure and Non-planned expenditure, Revenue expenditure and capital expenditure. Planned expenditure in that part of budgetary expenditure which is meant for finance the schemes and programmes framed under annual and five years plan or expenditure on unfinished task of the previous plan. Plan expenditure in mainly on the creation of assets. Non- plan expenditure is the expenditure on operating and maintaining existing educational infrastructure. So at the end of a five year plan, the recurring parts of Plan expenditure on different programmes or schemes become part of Non plan expenditure. Non plan expenditure is expected to increase steadily over the years. Another classification of public expenditure is expenditure on Capital account and revenue account. Former is expenditure on creation of assets and it is developmental in nature. Whereas the later is expenditure on normal running of the system it includes the expenditure on salaries etc. Bulk of resources spend on education in India are on Revenue account and small amount is spend on capital account. Capital expenditure and loans for education are quite meagre in comparison with the expenditure under Revenue. The share of capital expenditure in total expenditure is less than one percent. It does not mean that government is not spending money on the creation of assets. The reason behind this is that the total grant in aid provided for creation of assets booked under revenue account and not on capital account. It is important to look at the trends of Planned and Non Planned expenditure on education. This is because, as already mentioned, Non-plan expenditure largely reflects the recurring expenses in the education sector while the
Plan expenditure reflects new schemes and projects started by the government Table 2.

During 2012-13 Central governments total expenditure on education consists of $84.11 \%$ on planned and remaining $14.89 \%$ on Non planned expenditure. State government incur bulk of its expenditure on Non planned the share of Non planned expenditure in the total expenditure on revenue account was 83.60 percent the remaining 16.40 percent is the share of plan expenditure. About $82.72 \%$ of the Central government expenditure on education is under plan whereas in case of States/UTs it is only $21.03 \%$ in the year $2013-14$. Some trends have been observed on plan and Non plan expenditure.

The analysis shows that share of planned expenditure in the total expenditure on education incurred by centre, state and UTs has increased where as the share of Non- plan expenditure has declined. At state level the planned expenditure has shown increasing trends its share has gone up from 12.45 percent to 25.23 percent. The share of Non planned expenditure shows a declining trend its share has decline from - percent to 74.77 in 2013-14. Planned and Non planned expenditure incurred by the centre also show some trends the share of planned expenditure has increased and share of non planned has decline from - to 61.66 percent in 2013-14 Table 3.

The above data indicates some trends in the intra-sect oral composition of public expenditure. Government focusing on elementary education since independence. The share of elementary education in total expenditure on education was 50 percent. Since 2001 the share of elementary education in total expenditure has 
Citation: Tasleem Araf C (2016) Trends, Growth and Changing Patterns of Public Expenditure on Education in India. J Glob Econ 4: 226. doi: $10.4172 / 2375-4389.1000226$

marginally decline from over 50 percent to 44.59 percent in 2013-14. The percentage share of secondary education has also shown declining trends, its share has decline from 33.80 percent to 24.86 in 2013-14. Share of university and higher education in total expenditure increased from 14.71 to 24.47 in 2007-08 thereafter it starts declining. Presently the share of higher education in total expenditure on education is 15.29 percent. Government spend less than one percent of GDP on higher education, this has seriously hampered the quality of higher education in India. Significantly increased in the expenditure on technical education has been found. The share of technical education in total expenditure has increased substationally from 3\% in 2001 to percent to 15 percent in 2013-14.

\section{Conclusion}

India in the second most populas country in the world, having world largest school going age population. The combined public expenditure incurred by both central and state government on education hovering around three to four percent of GDP Since 2001. There are some advanced countries spending more than six percent of GDP on education like USA (6.4\%), New Zealand (6.9\%), Norway (6.5\%) and United Kingdom (6.3\%). Per capita expenditure on education in India is one of the lowest in the world. Shortage of funds acts as obstacles in quantative expansion and qualitative improvement on education. Govt spend less than one percent of GDP on higher education. There is need to increase spending on education beyond six percent of Gross Domestic Product.

\section{References}

1. Anuradha De, Tanuka E (2008) Public Expenditure on Education in India: Recent Trends and Outcomes. Research Consortium on Educational Outcomes and Poverty.

2. Jandhyala BGT (2006) On Allocating 6 Percent of GDP to Education. Economic and political weekly.

3. An analysis of Budgetary Expenditure on Education. Ministry of Human Development Govt of India various issues. 